\title{
Conformity Assessment to Development Plan Implementation as a Tool for Development Control in Kisii Town, Kenya
}

\author{
Wilfred Ochieng Omollo \\ Department of Planning and Development, Kisii University, Kenya, \\ wochieng@kisiiuniversity.ac.ke
}

DOI: $\underline{\text { http://dx.doi.org/10.4314/sajg.v7i3.10 }}$

\begin{abstract}
The objective of this study was to determine if the current land use development patterns in Kisii Town conformed to development zones in approved 1972 Kisii Town Physical Development Plan. Spatio-temporal analysis guided by Object Based Image Analysis (OBIA) was undertaken using QGIS software, integrating satellite image epochs of 2005, 2010 and 2017. Results showed that all approved development zones were not conformed to by ensuing land use development patterns, thus denoting nonconformity. The study also tested the hypothesis that there was no statistically significant difference between approved land use development patterns in the 1972 Kisii Town Physical Development Plan and ensuing land use development patterns in 2017. The test however found a significant difference between the two paired samples $(M=43.555, S D=34.661)$ and $(M$ $=36.344, S D=34.047), t(9)=4.03, p=0.003$. The null hypothesis was as a result rejected at 95\% confidence level. The study concluded that because conformity to the development plan declined by a mean of 7.206, its objective as a tool for development control in Kisii Town was not attained. Recommendation was made that since the plan is outdated, a comprehensive plan covering the entire town should be prepared to provide a framework for development control. Additionally, there is need to adopt a strict enforcement and monitoring regime that ensures compliance with the plan.
\end{abstract}

Keywords: Conformity, physical development plan, development control, Kisii Town.

\section{Introduction}

Although several studies have been conducted on evaluation of socio-economic policies, very few have examined how physical development plans may also be evaluated (Talen, 1996). While some scholars have endeavored to link policy implementation theory to planning practice, physical planners on the other hand are yet to develop a comparable methodology to assess the impacts of their plans (Berke et al., 2006). As such, it is not easy to determine if their objectives were attained. Berke and Godschalk (2009) also questioned why plans are not routinely evaluated to establish whether or not they meet set objectives after elapse of their implementation phases. They noted that regardless of the significance of land use planning to the profession of urban and regional planning, and the increasing number of evaluation studies by scholars, there is a gap in knowledge relating to physical development plan evaluation. This may suggest why Waldner (2004) interrogated why 
American planners kept asking residents to participate in preparation of new land use development plans, yet other similar plans were never evaluated to determine if they attained their intended objectives.

In the current study, it was also contended that failure to evaluate the ensuing land use development patterns to determine their conformity to the approved 1972 Kisii Town Physical Development Plan results to a missed opportunity by the planning authority in appreciating how to generally improve the urban development control framework in the perspective of competing land uses. From this background, Baer (2007) identified four connotations of the word "plan evaluation," centred on who carry out the evaluation, at what stage in the planning process, and with what techniques. Baer (2007) described development plan evaluation to entail: (i) plan assessment (confirming that the plan embodies its criteria); (ii) plan testing and evaluation (evaluating alternative ways to achieve a plan's goal); (iii) plan critique (a subjective review of a plan by other planners, similar to a movie review); (iv) comparative research and professional evaluation (comparing various plans, with or without considering outcomes); and (v) post-hoc evaluation of plan outcomes. The current study settled on the definition of evaluation as provided by Baer (2007), specifically, post hoc effects, that is, what happened to the plan? Was it useful? Did it attain its objectives of development control? According to Waldner (2004), post-hoc evaluation is also referred to as "monitoring or "retrospective evaluation.” It interrogates if the approved proposals in the development plan were carried out, and is also known as conformance, or compliance method.

While many studies have been undertaken on spatio-temporal urban land use change (for example Mugo, Kuria and Mubea, 2014; Mabaso et al., 2015; Padeiro, 2016), most of them are limited to general land use and land cover change extending over large spatial regions without due attention to proposed land use zones in physical development plans. Nevertheless, in situations where reference was made to physical development plans, while some studies focused on selected urban land use development patterns (Padeiro, 2016), those that successfully covered broad spectrum of planned urban land use (Mugo et al., 2014) overlooked the possible relationship between them in order to forecast the likelihood that some land use, in absence of development control, would transition to other land use classifications. A scarcity in literature also exist on how conformity to development plans may be spatially and statistically assessed, a gap filled in the current study.

\section{Objective and Hypothesis of the Study}

From the introductory review, the objective of this study was to determine if the current land use development patterns in Kisii Town conformed to the approved land use development zones in the 1972 Kisii Town Physical Development Plan. The corresponding null hypothesis was that there was no statistically difference between approved land use development patterns in the 1972 Kisii Town Physical Development Plan and subsequent land use development patterns in 2005, 2010 and 2017. This study specifically addresses the limitations of previous studies by demonstrating that 
conformity assessment to physical development plans may be tested by a concurrent triangulation of spatio-temporal (change detection over time and space) and quantitative analyses.

\section{Materials and Methods}

\subsection{Study Area}

Kisii Town is located in South-Western Kenya, and lies approximately $400 \mathrm{~km}$ West of Nairobi City County, the capital City of Kenya. Administratively, the town is the capital of Kisii County, one of the 47 County Governments that collectively constitute the Republic of Kenya (Figure 1). As concerns spatial coverage, Kisii Town covers $34 \mathrm{~km}^{2}$. With reference to physical planning, development control in the town is currently effected through a plan prepared in 1972, covering $4.35 \mathrm{~km}^{2}$, implying that $87.21 \%$ of land remains unplanned, thus a drawback for effective development control. Despite this apparent limitation, the plan to date remains as the only spatial framework for undertaking development control.

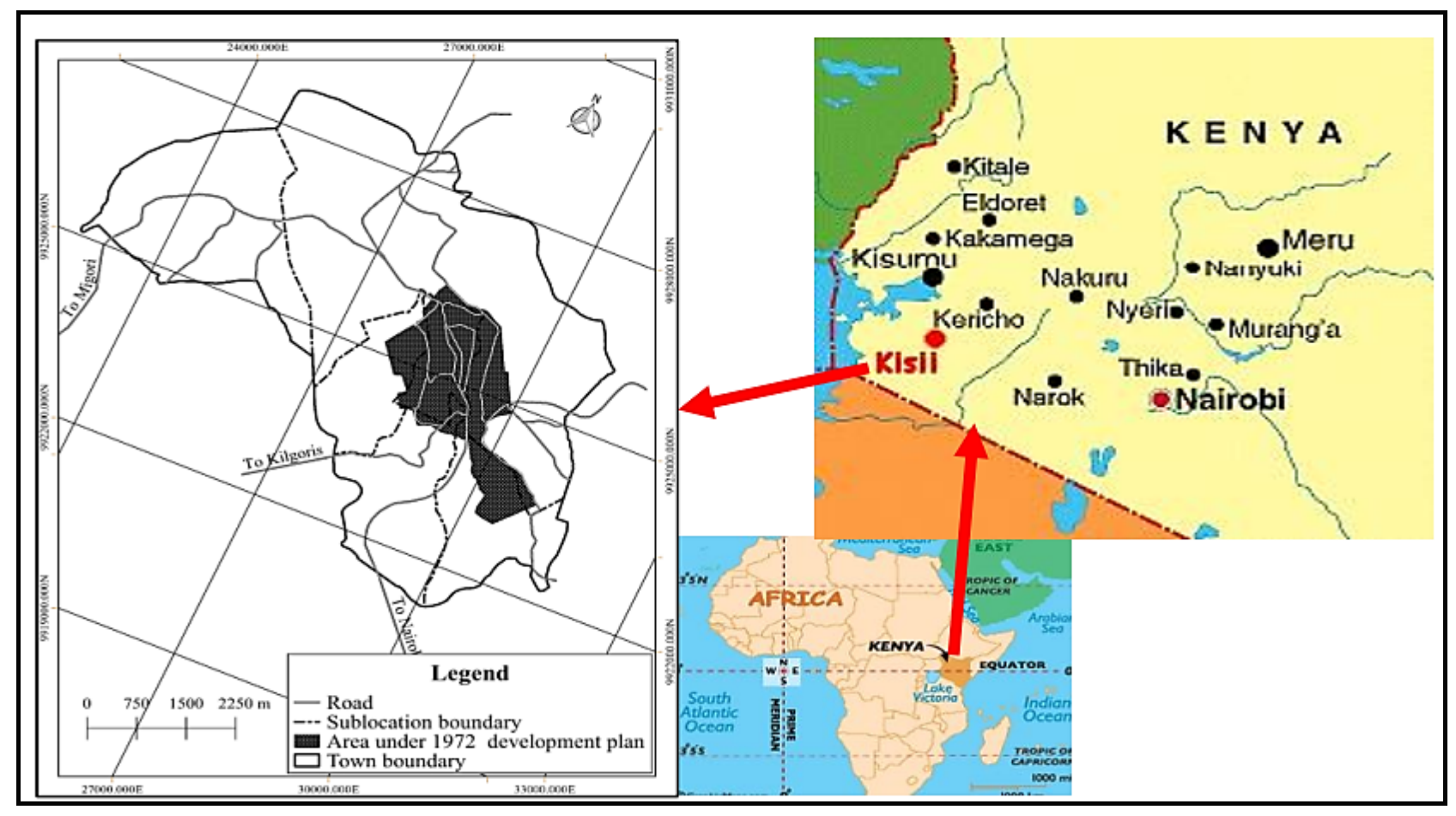

Figure 1. Location of the study area

Source: Omollo, et al. (2018)

\subsection{Source of Data for Spatial-Temporal Analysis}

Data collection for spatio-temporal land use conformity analysis to address the research objective and hypothesis was attained using preprocessed high resolution multispectral satellite images of three epochs (2005, 2010 and 2017) procured from the Regional Centre for Mapping of Resources for Development, Nairobi, Kenya. Epochs’ specifications were as presented in Table 1. 
Table 1. Description of satellite data for spatial analysis

\begin{tabular}{|c|c|c|c|c|c|}
\hline Operator & Satellite & Date & Bands & Resolution & Band Combination \\
\hline DigitalGlobe & $\begin{array}{l}\text { QuickBird-2 } \\
\text { (QB-2) }\end{array}$ & $\begin{array}{l}10^{\text {th }} \text { July, } \\
2005\end{array}$ & $\begin{array}{l}\text { Four multispectral } \\
\text { band resolution of } \\
2.4 \text { meters }\end{array}$ & $\begin{array}{l}\text { Panchromatic/ } \\
\text { spatial resolution } \\
\text { of } 0.61 \text { metres. }\end{array}$ & $\begin{array}{l}\text { Blue: } 430 \text { - } 545 \mathrm{~nm} \\
\text { Green: } 466 \text { - } 620 \mathrm{~nm} \\
\text { Red: } 590 \text { - } 710 \mathrm{~nm} \\
\text { Near-IR: } 715 \text { - } 918 \mathrm{~nm}\end{array}$ \\
\hline DigitalGlobe & $\begin{array}{l}\text { WorldView- } \\
2 \text { (WV02) }\end{array}$ & $\begin{array}{l}17^{\text {th }} \\
\text { December, } \\
2010\end{array}$ & $\begin{array}{l}\text { Eight-band } \\
\text { multispectral } \\
\text { imagery } \\
\text { resolution of } 1.84 \\
\text { metres }\end{array}$ & $\begin{array}{l}\text { Panchromatic/ } \\
\text { spatial resolution } \\
\text { of } 0.46 \text {. }\end{array}$ & $\begin{array}{l}\text { Coastal: } 400 \text { - } 450 \mathrm{~nm} \\
\text { Red: } 630-690 \mathrm{~nm} \\
\text { Blue: } 450 \text { - } 510 \mathrm{~nm} \\
\text { Red Edge: } 705-745 \mathrm{~nm} \\
\text { Green: } 510 \text { - } 580 \mathrm{~nm} \\
\text { Yellow: } 585-625 \mathrm{~nm} \\
\text { Near-IR1: } 770-895 \mathrm{~nm} \\
\text { Near-IR2: } 860-1040 \mathrm{~nm}\end{array}$ \\
\hline DigitalGlobe & WV-03 & $\begin{array}{l}19^{\text {th }} \\
\text { January, } \\
2017\end{array}$ & $\begin{array}{l}\text { Eight-band } \\
\text { multispectral } \\
\text { imagery of } 1.24 \\
\text { metres resolution }\end{array}$ & $\begin{array}{l}\text { Panchromatic/ } \\
\text { spatial resolution } \\
\text { of } 0.31 \text { metres. }\end{array}$ & $\begin{array}{l}\text { Coastal: } 397-454 \mathrm{~nm} \\
\text { Red: 626-696 nm } \\
\text { Blue: 445-517 nm } \\
\text { Red Edge: 698-749 nm } \\
\text { Green: 507-586 nm } \\
\text { Yellow: 580-629 nm } \\
\text { Near-IR1: 765-899 nm } \\
\text { Near-IR2: } 857-1039 \mathrm{~nm}\end{array}$ \\
\hline
\end{tabular}

The study used QGIS software, version 3.0.2 for spatial analysis. It was preferred owing to its versatility that incorporates plugins which are easily downloadable and frequently updated. It likewise readily integrates with Google satellite which eases georeferencing. Additionally, being an open source software, no costs were incurred in its acquisition. QGIS is also very fast in processing of spatial data compared to other software such as ArcGIS. This is because it uses a small amount of time to carry out complex geospatial tasks, attributable to its robust internal structure.

\subsection{Process for Spatio-Temporal Conformity Analysis}

The process followed in land use classification and spatial analysis was as follows:

a) Scanning of approved 1972 Kisii Town Physical Development Plan base map and subsequently georeferencing it using 20 Ground Control Points (GCPs). Universal Traverse Mercator (UTM) Zone 37S was used as the coordinate reference system.

b) Vectorising of georeferenced base map to generate planned land use development zones.

c) Undertaking land use classification of vectorised base map into distinct planning zones, which are currently used by the County Government of Kisii in enforcing development control.

d) Clipping of the boundary covered by the physical development plan from images covering the wider Kisii Town to obtain land use epochs for 2005, 2010 and 2017.

e) Undertaking of semi-automated Object Based Image Analysis (OBIA) using Orfeo ToolBox (OTB) by grouping pixels into objects based on spectral similarity in land use cover for each of the clipped 2005, 2010 and 2017 epochs and then overlaying each classified epoch with the vectorised and classified approved development zones in the 1972 development plan. 
f) Determining accuracy assessment for 2005, 2010 and 2017 land use classifications from the error matrices for each year. This also generated Kappa Coefficient, symbolized as $\mathrm{K}_{\text {hat }}$.

g) Computing the extent of land use change in hectares from each consequential spatial overlay for the years 2005, 2010 and 2017 in relation to the1972 approved physical development plan.

\subsection{Test of Hypothesis}

The research hypothesis was tested using paired sample t-test where the two pairs were the arithmetic means of areas (in hectares) covered by all ten (10) land use development patterns in the 1972 Kisii Town Physical Development Plan against their corresponding arithmetic means in 2017 land use map (in hectares).

\section{Results and Discussions}

\subsection{Land Use Zoning in 1972 Kisii Town Physical Development Plan}

Land use classification in the Kisii Town Physical Development Plan is effected through zoning, described by Brown et al. (2018) as a tool used to specify permitted development on a specific area of land, outlining the use category of land by prescribing allowable and prohibited developments. The aim is to preserve community "character". Development control in Kisii Town is therefore enforced through a development plan that is spatially segregated into zoning districts, each outlining development control objectives. This provides the basis for plan implementation, along with ensuring that resulting land use development patterns conforms to specified zoning conditions. Objectives of the ten (10) zoning districts in the physical development plan are to:

a) Provide clear definitions for land use activities that are permitted.

b) Preserve and provide for open space and recreational amenities.

c) Provide a tool for enforcement of approved applications for development permissions.

d) Outline considerations that must be taken into account if an area is to be changed, extended or subdivided, either for an individual plot or parcel of land within a local plan, or a broad land use zoning classification in the development plan.

e) Provide a guide for developers and practitioners in promotion of harmonious spatial development through their activities.

Each of these zones in the physical development plan are described in Table 2 and further illustrated in Figure 2 in terms of spatial coverage. 
Table 2. Land use allocation in 1972 Kisii Town Physical Development Plan

\begin{tabular}{llll}
\hline $\begin{array}{l}\text { Approved Zone/ } \\
\text { User }\end{array}$ & $\begin{array}{l}\text { Zonal/User } \\
\text { Allocation (Ha) }\end{array}$ & $\begin{array}{l}\text { Percentage } \\
\text { Coverage (\%) }\end{array}$ & Colour Code \\
\hline Residential & 85.86 & 19.71 & Brown \\
Industrial & 9.02 & 2.07 & Purple \\
Education & 75.98 & 17.45 & Orange \\
Recreational & 75.90 & 17.43 & Green \\
Public purpose & 67.46 & 15.49 & Yellow \\
Commercial & 15.38 & 3.53 & Red \\
Public utilities & 3.92 & 0.90 & Blue \\
Transportation & 75.00 & 17.22 & Grey \\
Agricultural & 13.54 & 3.11 & Pale green \\
Undeveloped land & 13.44 & 3.09 & Light brown \\
Total & $\mathbf{4 3 5 . 5 0}$ & $\mathbf{1 0 0 . 0 0}$ & \\
\hline
\end{tabular}

Having described the proposed land use development zones, the overall spatial organisation in the form of a land use map depicting allocation for each proposed development zone in the study area is further presented (Figure 2).

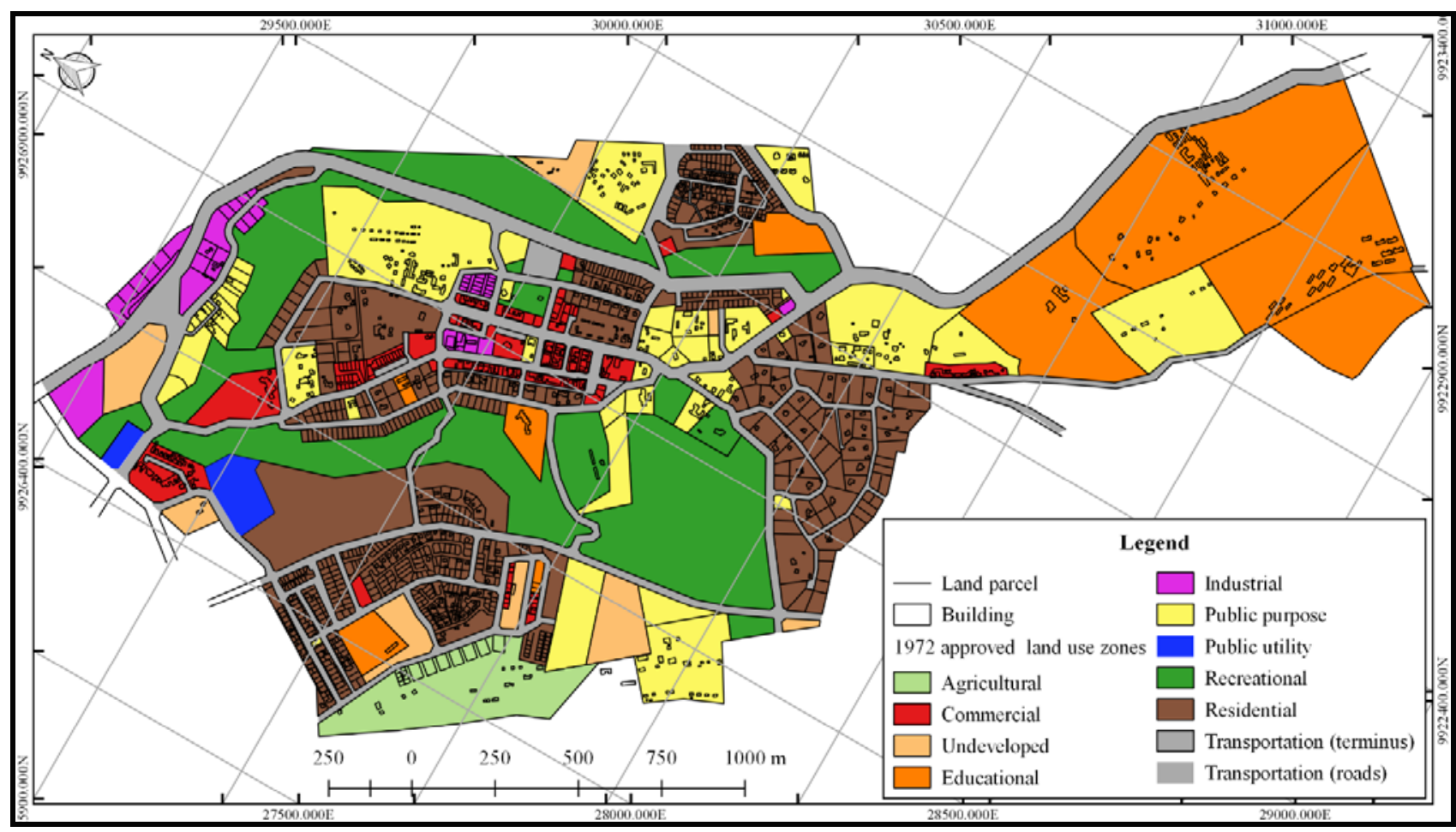

Figure 2. Approved land use zones in 1972 Kisii Town Physical Development Plan

An exceptional trait in the plan was a recreational zone (green space) modelled to form an almost perfect ring like enclosure around the town centre. As observed by Lee et al. (2015), such an urban green space provides environmental benefits through their effects on negating urban heat, offsetting greenhouse gas emissions, and attenuating storm water. They also have direct health benefits by providing urban residents with spaces for physical activity and social interaction, permitting psychological restoration to take place. Subsequent subsections determines if ensuing land use development patterns conforms to the development plan's zoning proposals, a basis for enforcing development control. Analysis of land use change is therefore undertaken for 2005, 2010 and 2017. 


\subsection{Extent of Conformity with the Development Plan in 2005}

Overall accuracy for 2005 land use classification for was 90.82\%, which was above Anderson et al. (1976) recommendation of $85 \%$. In addition, the overall $K_{\text {hat }}$ classification was 0.83 , which Landis and Koch (1977) graded as almost perfect agreement. By 2005, residential land use still maintained the highest proportion of resultant land use patterns as corroborated by $22 \%$. This was followed by educational land use (20\%); transportation (17\%); public purpose (16\%); recreational (14\%); commercial (5\%); undeveloped land (2\%); agricultural (2\%) and public utilities and industrial (respectively 1\%). Table 3 shows the extent of conformity between 1972 and 2005. Spatial extent of conformity is further depicted in Figure 3.

Table 3. Extent of conformity to the development plan, 1972 and 2005

\begin{tabular}{lccc}
\hline Development Zone & \multicolumn{2}{c}{ Years } & Conformance Variation (\%) \\
\cline { 2 - 3 } & $\mathbf{1 9 7 2}$ & $\mathbf{2 0 0 5}$ & \\
\hline Residential & 85.86 & 102.81 & 19.74 \\
Industrial & 9.02 & 5.99 & -33.59 \\
Educational & 75.98 & 86.75 & 14.73 \\
Recreational & 75.90 & 63.64 & -16.15 \\
Public purpose & 67.46 & 61.48 & -8.86 \\
Commercial & 15.38 & 22.26 & 44.73 \\
Public utilities & 3.92 & 3.43 & -12.50 \\
Transportation & 75.00 & 74.84 & -0.21 \\
Agricultural & 13.54 & 7.81 & -42.32 \\
Undeveloped land & 13.44 & 7.77 & -42.19 \\
\hline
\end{tabular}

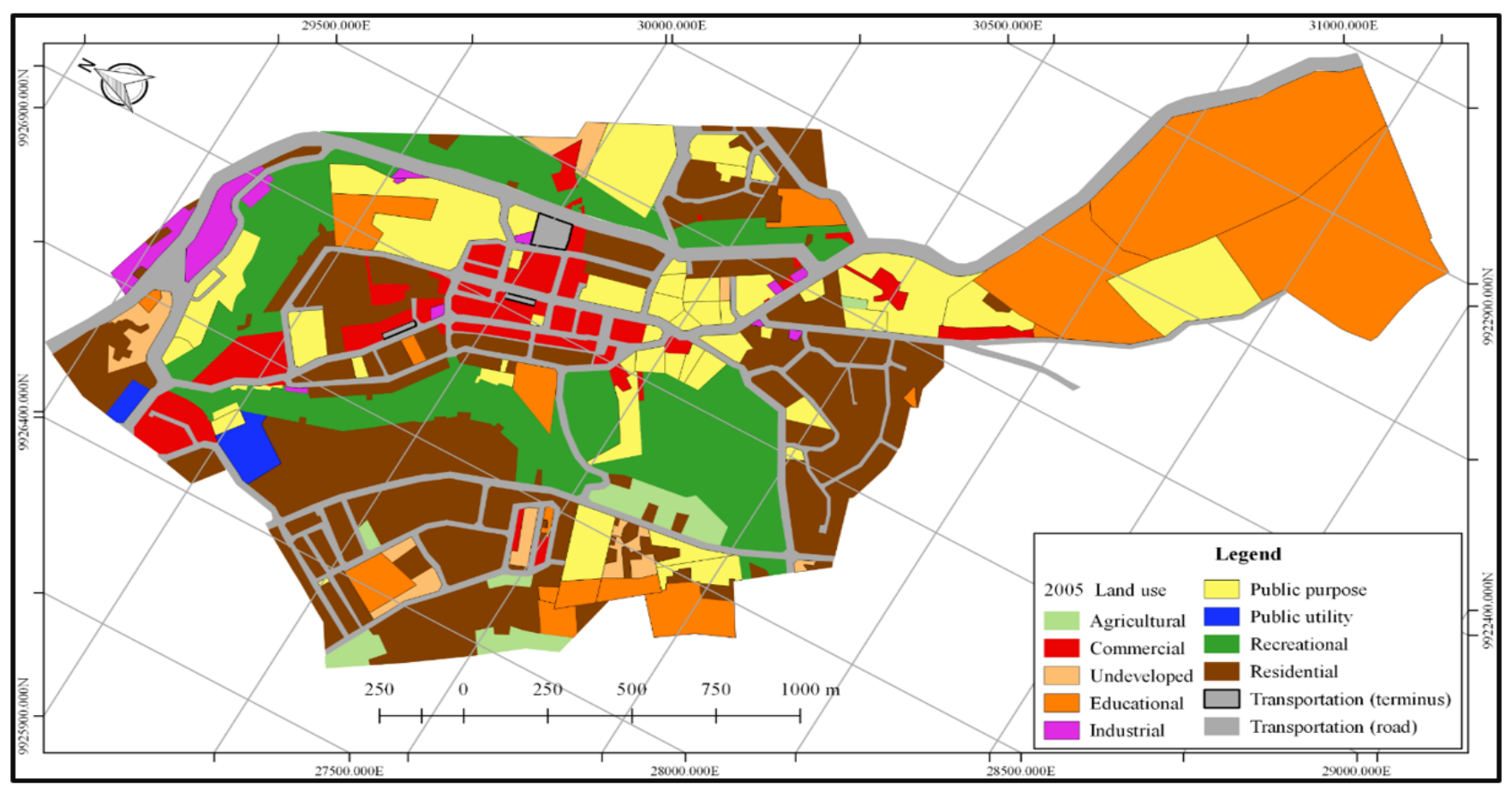

Figure 3. Land use map in 2005

While positive nonconformity indicates exceeding prescribed planned land use coverage for a zone owing to increased Land Consumption Rate (LCR) and declining Land Absorption Coefficient 
(LAC), negative conformity in contrast denotes loss of land as may be occasioned by change or extension of users. Table 3 further brings to light that comparatively, while residential land use covered 85.86 hectares as planned in 1972, the same increased 102.81 hectares in 2005, in consequence a nonconforming increment by $19.74 \%$. In the same period, commercial land use increased from 15.38 hectares in 1972 to 22.26 hectares in 2005, indicating the highest positive nonconformity of $44.73 \%$. Other land uses which also registered nonconformities included public purpose and industrial at $-8.86 \%$ and $-33.59 \%$ in that order. Agricultural land use largely recorded the highest loss as publicised by a nonconformity of $-43.32 \%$ followed by undeveloped land, 42.19\%, industrial, $-33.59 \%$, and recreational $-16.15 \%$. It is nevertheless observed that public purpose and transportation zones posted the lowest negative nonconformities, though not favourable if contextualised in terms of sustainable development control.

\subsection{Extent of Conformity with the Development Plan in 2010}

After taking note of the emerging differences between approved land uses in 1972 against those that successively followed in 2005, and in so doing unveiling the extent of spatial nonconformity, this subsection further determines the extent of conformity to the approved physical development plan by subsequent land use patterns in 2010. This was also attained by making reference to the land use development patterns in 1972 which were used as the base for progressively determining extent of spatial conformity (Table 4). Generally, the overall accuracy for 2010 classification was 90.82\%, also greater than Anderson et al. (1976) recommended level of $85 \%$. The $K_{\text {hat }}$ classification of 0.85 also portrayed a strong assessment and good accuracy.

Table 4: Extent of conformity to the development plan, 1972 and 2010

\begin{tabular}{|c|c|c|c|}
\hline \multirow[t]{2}{*}{ Development Zone } & \multicolumn{2}{|c|}{ Years } & \multirow[t]{2}{*}{ Conformance Variation (\% } \\
\hline & 1972 & 2010 & \\
\hline Residential & 85.86 & 103.23 & 20.23 \\
\hline Industrial & 9.02 & 7.69 & -14.74 \\
\hline Education & 75.98 & 86.38 & 13.69 \\
\hline Recreational & 75.90 & 58.06 & -23.51 \\
\hline Public purpose & 67.46 & 57.88 & -14.20 \\
\hline Commercial & 15.38 & 25.77 & 67.55 \\
\hline Public utilities & 3.92 & 2.28 & -41.84 \\
\hline Transportation & 75.00 & 72.91 & -2.79 \\
\hline Agricultural & 13.54 & 13.47 & -0.52 \\
\hline Undeveloped land & 13.44 & 7.33 & -45.46 \\
\hline
\end{tabular}

Research findings drew attention that residential zones not only maintained the highest coverage in 2010, but equally recorded a significant positive nonconformity of up to $20.23 \%$, demonstrating increased demand for land towards supporting more urban housing development. This contributed to land use densification, an assertion supported by a trend where vertical developments of residential apartments gained prominence in the town during this period, thereby underpinning the concept of “compact city”. However, in absence of operational development control, increasing 
densities have not contributed to sustainable development in Kisii Town. Commercial land use development further expanded by $67.55 \%$, demonstrating the period when the town was designated as the administrative capital of Kisii County upon promulgation of the Constitution of Kenya (2010). Conversely, undeveloped land declined by $45.46 \%$. To additionally determine conformity to the approved physical development plan, by 2010, the spatial structure where zoned recreational land use forms an almost ring like pattern encapsulating the central business district remains evident albeit progressive encroachment by other users (Figure 4).

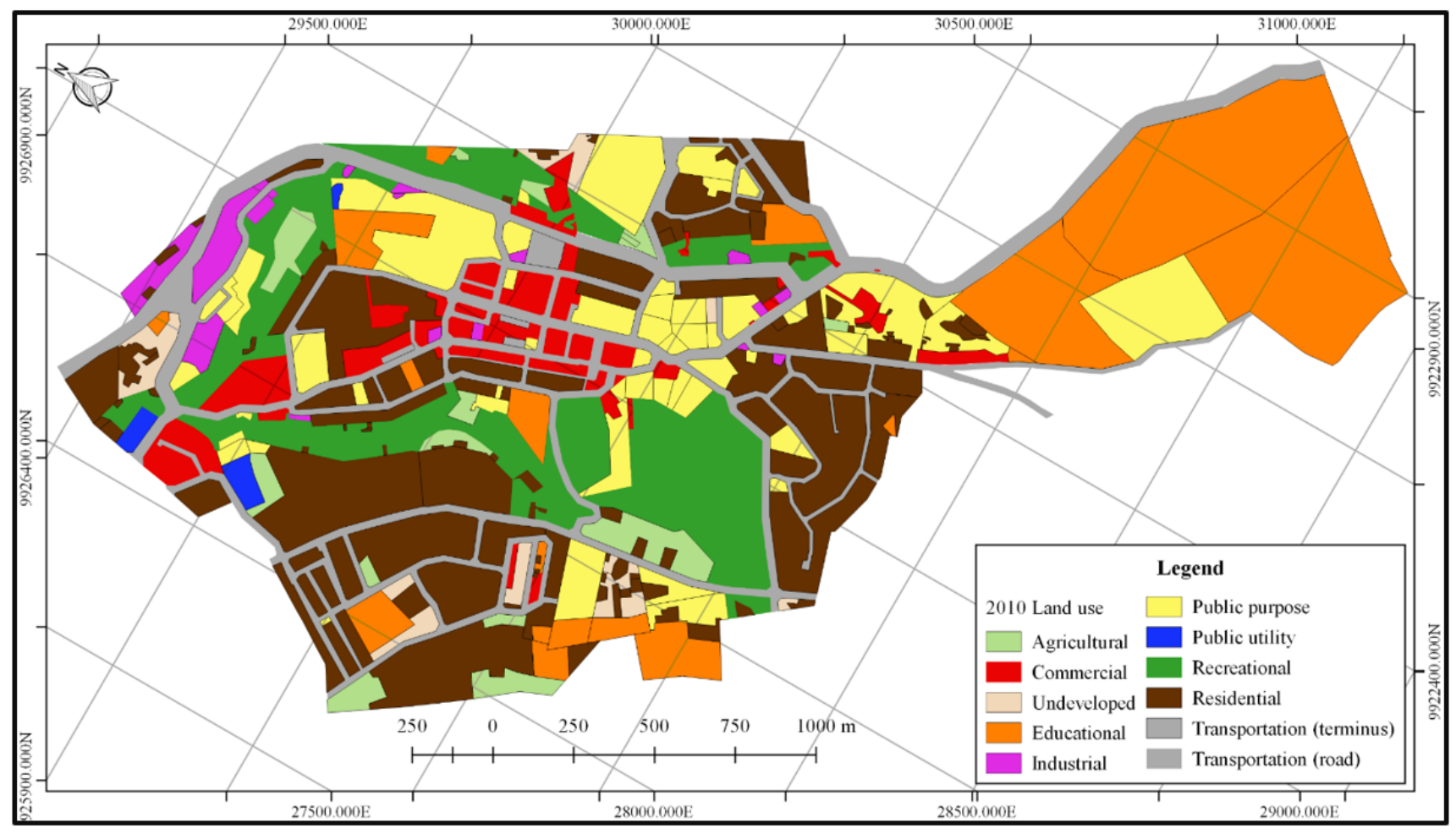

Figure 4. Land use map in 2010

In reference to Table 4 as read with Figure 4, during this period under assessment, industrial land use declined by $14.74 \%$, a trend occasioned by its conversion to accommodate increased public purpose land use. Commercial land use however underwent through notable expansion of up to $67.55 \%$, on the account of predominantly extending to land uses that were previously planned for public purpose and recreation (riparian reserves). Agricultural land use (cultivation agriculture) on the contrary underwent through a marginal decline (0.52\%) attributable to influence by an increased demand for residential developments, thus further denoting lack of effective development control by all the previous planning authorities in Kisii Town. In the same vein, educational land use expanded to $13.69 \%$ as the demand for more schools escalated on account of a corresponding increase in urban population, in the end influencing conversion of agricultural land use. Transportation zones, mainly roads, witnessed a decline attributable to illegal encroachment on road reserves by commercial developments as illustrated in the land use classification map for 2010. Other land use categories whose planned areas purposely reduced included public utilities (41.84\%); and recreational (-23.51\%). To this point, it is manifest from the foregoing findings that successive land use patterns do not conform to the approved physical development plan. 


\subsection{Extent of Conformity with the Development Plan in 2017}

By May, 2017, the top three dominant land uses were residential (28\%); educational (21\%); and transportation (17\%). This likens to 2005 where the observed dominant land use development patterns were residential (22\%), educational (20\%) and public purpose (16\%) respectively. Regarding spatial organisation and structure, analysis further demonstrates that land originally zoned for recreational purpose with a particular mention of strategic riparian reserves went through substantive and uncontrolled extensions and change of users. This expansive zone mainly attracted commercial and residential developments. In so doing, it became a casualty of rapid population explosion occasioned by increased demand for land to sustain expansion of residential and commercial developments (Figure 5).

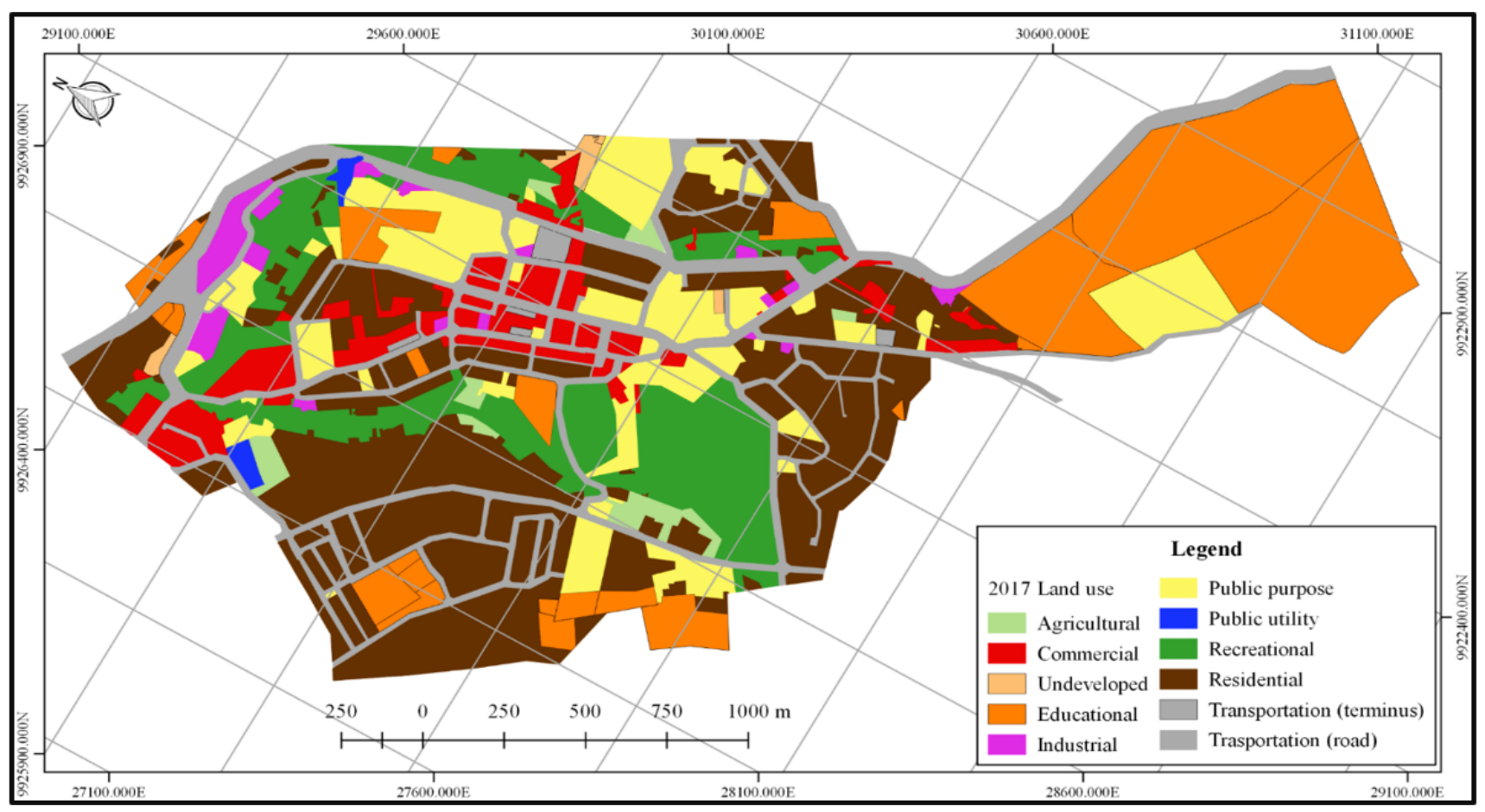

Figure 5. Land use map in 2017

Conformity land use analysis of the physical development plan implementation continued by determining the spatial differences between subsequent land use development patterns in 2017 against those planned 1972 (Table 5). The overall accuracy attained for the 2017 classification was 92.07\%. Moreover, the resultant $\mathrm{K}_{\text {hat }}$ classification was also 0.87 , which was greater than 0.8 , hence further depicting a strong assessment and good accuracy of the classification. 
Table 5. Extent of conformity to the development plan, 1972 and 2017

\begin{tabular}{lccc}
\hline \multicolumn{1}{c}{ Development Zone } & \multicolumn{2}{c}{ Years } & Conformance Variation (\%) \\
\cline { 2 - 3 } & $\mathbf{1 9 7 2}$ & $\mathbf{2 0 1 7}$ & \\
\hline Residential & 85.86 & 119.98 & 39.73 \\
Industrial & 9.02 & 7.25 & -19.62 \\
Education & 75.98 & 89.11 & 17.78 \\
Recreational & 75.90 & 55.81 & -26.45 \\
Public purpose & 67.46 & 53.04 & -21.38 \\
Commercial & 15.38 & 25.49 & 65.73 \\
Public utilities & 3.92 & 1.97 & -49.74 \\
Transportation & 75.00 & 74.24 & -1.01 \\
Agricultural & 13.54 & 5.82 & -57.00 \\
Undeveloped land & 13.44 & 2.01 & -75.00 \\
\hline
\end{tabular}

In terms of spatial variations, commercial land use registered the highest positive change (65.73\%), followed by residential land use, 39.73\%, and educational, 17.78\%. Remarkable expansion of these categories of land use was also stimulated by an analogous demand occasioned by increased population in Kisii Town (Table 5). According to Miruka (2010), the town offered solace to many entrepreneurs after the 2008 post-election violence that affected Kenya. During this time, a majority of entrepreneurs from neighbouring towns such as Kisumu, Kericho and Eldoret migrated to the town, further transforming its stature in land use. This contributed to increased economic activities resulting in a multiplier effect in growth of real estate as well as industrial and commercial activities. It was however unfortunate that this rapid growth rate was not concomitant with effective development control. The desire to acquire additional land in support of building development may have contributed to the loss of land set aside for recreation (a variance of 26.45\%) and agricultural (a variance of $-57.00 \%$ ). The study similarly determined key beneficiaries of the overall land use change in the study area between 1972 and 2017. It was evident that by May, 2017, much of the land use transitions were in favour of residential land use developments (37\%), a factor induced by increased population that created demand for more dwelling units. Suffice it to say that residential land use influenced transition of all land use categories apart from public utility land use. The next two top recipients of the overall land use change were educational (24\%) and commercial (21\%). Public utility and undeveloped land uses however never attracted and new land use (s).

\subsection{Correlation between Land Use Development Patterns}

From the foregoing spatio-temporal analysis, a correlational analysis was additionally conducted to determine the strength of relationships between various observed land use development patterns between 1972 and 2017 using Pearson’s bivariate correlation (Table 6). 
Table 6. Correlational matrix for selected land uses

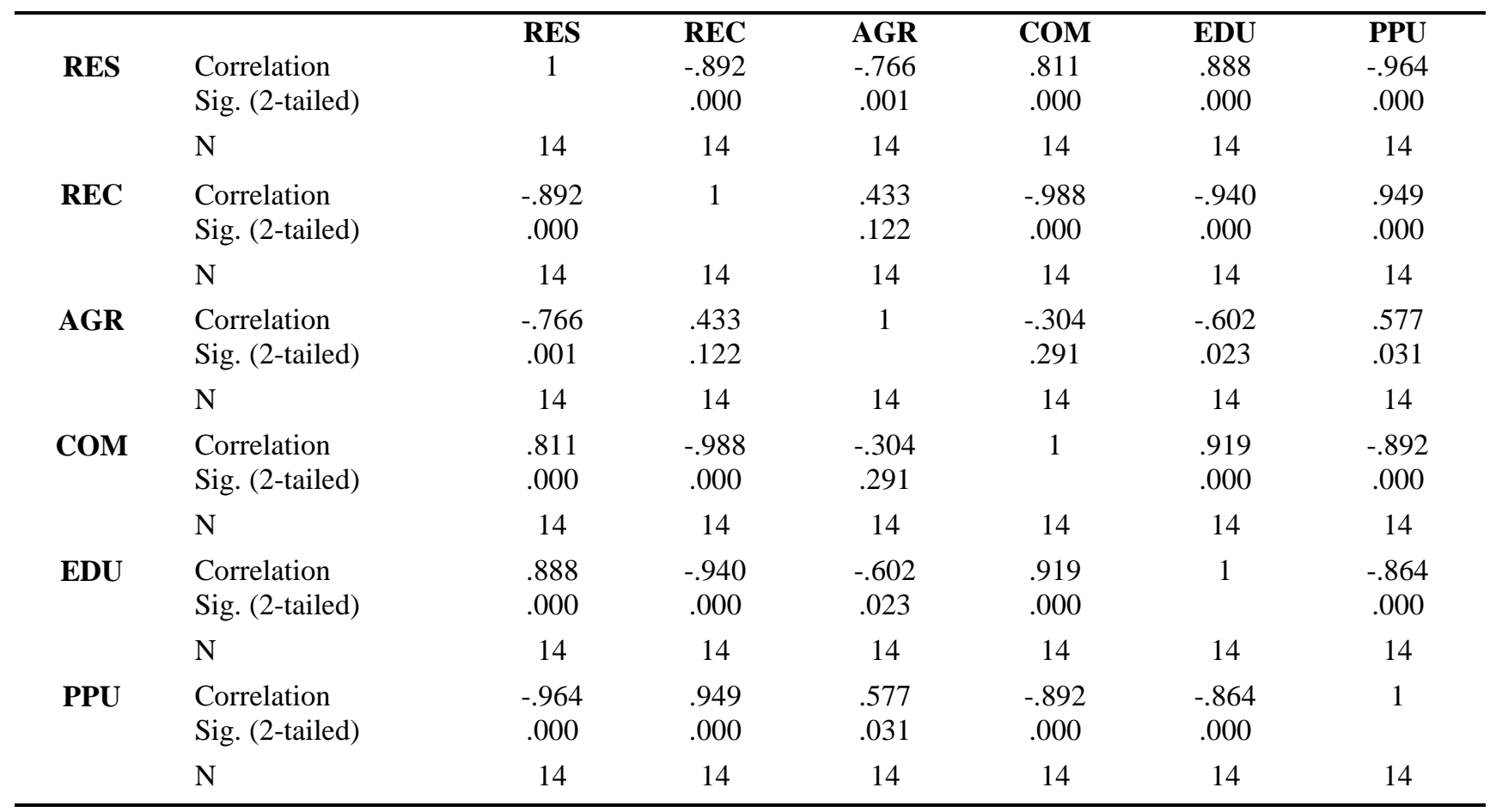

Note: RES = residential; REC = recreational; $\mathrm{COM}=$ commercial; $\mathrm{AGR}=$ agricultural, $\mathrm{EDU}=$ educational and PPU = public purpose land uses.

Attention is drawn that Pearson's correlation coefficient between residential land use on one hand, and recreational $(r=-0.892, p=0.000)$ agricultural $(r=-0.766, p=0.001)$ and public purpose ( $r=-0.964, p=0.000$ ) land uses on the other hand had high significant negative linear correlations, implying that an increase in residential land use resulted in a similar decrease of these three (3) land use categories. At the same time, residential land use had a high positive correlation with commercial land use $(r=0.811, p=0.000)$ and educational land use $(r=0.888, p=0.000)$. This indicates a symbiotic relationship, a condition whereby as residential land use increases, a demand is created by residents for additional educational facilities and commercial establishments. Further analysis showed that recreational land use had a very high negative linear correlation with commercial land use $(r=0.988, p=0.000)$ and educational land use $(r=-0.940, p=0.000)$, portending that an increase in commercial and educational land uses negatively contributed to a parallel decrease in recreational land use in the study area. Likewise, recreational land use demonstrated a significant strong positive correlation $(\mathrm{r}=0.949, \mathrm{p}=0.000)$ with public purpose land use. This suggested that as more land for recreational use became readily available, on account of poor development control, this increasingly attracted developers, especially of churches which were noticeably located in these zones. Concerning agricultural land use, a moderate negative correlation between it and educational land use $(r=-0.602, p=0.023)$ and an additional moderate positive correlation with public purpose land use $(r=0.577, p=0.031)$ respectively ensued. It consequently implies that in the event of increased demand for educational land use in absence of development control, this is likely to contribute to a decline in agricultural land use, hence, should more land for agricultural land use became available, it would create an opportunity for an 
expansion of public purpose land use. Commercial land use reported a high positive and significant linear correlation with residential $(r=0.811, p=0.000)$ and educational $(r=0.919, r=0.000)$ land uses. This similarly demonstrates a reciprocal relationship whereas expansion of urban dwelling units increased; a demand was created for additional investment in educational facilities. However, a high negative correlation with recreational $(r=0.988, p=0.000)$ and public purpose $(r=-.892, p=$. 000) land uses emerged suggesting an increase in commercial land significantly resulted in a decline of recreational and public purpose land uses.

\subsection{Test of Hypothesis}

The research hypothesis was tested using paired sample t-test to determine if the mean difference between two sets of observations was zero. Two pairs of observations were the arithmetic means of approved ten (10) land use patterns in the 1972 development plan and resultant arithmetic means of land use development patterns in 2017 for all land use categories. The test found a statistically significant difference between the 1972 land use development patterns $(\mathrm{M}=43.555, \mathrm{SD}=34.661)$ and 2017 land use development patterns $(M=36.344, \mathrm{SD}=34.047), \mathrm{t}(9)=4.03, \mathrm{p}=0.003$. The null hypothesis was therefore rejected at 95\% confidence level. Results showed that on average, conformity to the plan declined by a mean of 7.206, implying that its objectives were never met since it has significantly deviated from the approved land use development zones.

\section{Conclusion}

The study has demonstrated that the current land use development patterns do not conform to the approved development zones in 1972 Kisii Town Physical Development Plan. The plan therefore offers limited contribution towards an effective development control in Kisii Town, a problem that continues irrespective of the legal framework that has since independence given the former and current planning authorities the powers to regulate land use. As a policy implication, it is recommended that the County Government of Kisii should prepare a comprehensive development plan covering the entire town. Once prepared, a comprehensive GIS should be established to aid in continuous monitoring of conformity. Additionally, there is need to strictly enforce compliance with physical planning standards, a strategy for promoting conformity. This study therefore contributes to the existing body of literature by corroborating that extent of implementing approved physical development plans may be spatially and quantitatively determined.

\section{References}

Anderson, J.R., Hardy, E.E., Roach, J.T. \& Witmer, R.E. 1976, 'A land use and land cover classification system for use with remote sensor data: Geological Survey Professional Paper 964.'

Baer, W.C. 2007, 'General plan evaluation criteria: An approach to making better plans', Journal of the American Planning Association, vol. 63, no. 3, pp.329-344.

Berke, P. \& Godschalk, D. 2009, 'Searching for the good plan: A meta-analysis of plan quality studies,' Journal of Planning Literature, vol. 23, no. 3, pp.227-240. 
Berke, P., Backhurst, M., Day, M., Ericksen, N., Laurian, N., Crawford, L. \& Dixon, J. 2006, 'What makes plan implementation successful? An evaluation of local plans and implementation practices in New Zealand', Environment Planning and Design, vol. 33, no. 4, pp.581-600.

Landis, J.R., Koch, G.G. 1977, 'The Measurement of Observer Agreement for Categorical Data', Biometrics, vol. 3, no. 1, pp.159-174. <http://www.jstor.org/stable/2529310>

Lee, A.C., Jordan, H.C. \& Horsley, J. 2015, 'Value of urban green spaces in promoting healthy living and wellbeing: prospects for planning’, Risk Management Health Policy, vol. 8, pp.131-137.

Mabaso, A., Munyaradzi, D.S., Chirisa, I., Zanamwe, L., Gwitira, I. \& Bandauko, E. 2015, 'Urban physical development and master planning in Zimbabwe: An assessment of conformance in the City of Mutare', Journal for Studies in Humanities and Social Sciences, vol. 4, no.1, pp.72-88.

Miruka, B. 2010, 'Post-poll immigrants spur Kisii town's growth', Standard Newspaper, viewed 26 June 2018, <https://www.standardmedia.co.ke/business/article/2000014447/post-poll-immigrants-spur-kisiitowns-growth>.

Mugo, R.N., Kuria, R.K. \& Mubea, K. 2014, 'Assessing the compliance of physical plans using GIS and remote sensing: A Case of Olkalou Town', International Journal of Science and Research, vol. 3, no.12, pp.925-934.

Omollo, W.O, Hayombe, P.O. \& Owino, F.O. (2018), 'Compliance with Physical Planning Standards by Residential Developments in Kisii Town, Kenya’, Architecture Research. vol. 8, no.2, pp. 62-73.

Padeiro, M. 2016, 'Conformance in land-use planning: The determinants of decision, conversion and transgression', Land Use Policy, vol. 55, pp.285-299.

Republic of Kenya. 2012, 'County Government Act', Government Printer, Nairobi.

Republic of Kenya. 1999, 'Population and Housing Census Survey’, Government Printer, Nairobi.

Republic of Kenya. 2012, 'Urban Areas and Cities Act', Government Printer, Nairobi.

Schultz, R.C., Colletti, J.P., Isenhart, T.M., Marquez, C.O., Simpkins, W.W. \&. Ball, C.J. 2000, 'Riparian Forest Buffer Practices', In Garett, H.E., et al. (eds.), North American Agroforestry: An integrated science and practice. American Society of Agronomy, Inc. Madison, pp.189-281.

Talen, E. 1996, 'Do plans get implemented? A review of evaluation in planning', Journal of

Planning Literature, vol. 10, no. 3, pp.248-259.

Waldner, L.S. 2004, 'Planning to perform: Evaluation models for city planners', Berkeley Planning Journal, vol. 17, no. 1, pp.1-28. 